$J J M L L$

\title{
Pragmatic Analysis of Impolite Speech Acts and their Verbal Responses in Shakespeare's Hamlet
}

\author{
Sahira Mousa Salman \\ Ministry of Higher Education \& Scientific Research \& Development Office, Iraq
}

Abdali H. Shihan Al-Saidi

Department of English Language and Literature, Thi Qar University, Iraq

Abed Shahooth khalaf *

Department of English Language and Literature, University of Anbar, Iraq

Received on: 18-8-2020

Accepted on: 4-1-2021

\begin{abstract}
This study attempts a pragmatic analysis of impoliteness strategies utilized by Hamlet in his interactions with other characters in the play. It aims at examining other characters' verbal responses to Hamlet's impolite speech acts and identifying which response strategies are more frequently associated with which impoliteness strategies. To achieve these objectives, the study collates (32) impolite speech acts along with their responses from Hamlet to represent its data for analysis. Out of these data, (15) examples are randomly selected to analyze the impoliteness strategies utilizing Culpeper's (1996/2011/2017) and Culpeper, Bousfield and Wichmann (2003) models. Moreover, Bousfield's (2008) model was adopted to account for the interlocutors' responses to impoliteness. The findings of the study show that mock impoliteness, bald on record impoliteness and positive impoliteness are repeated in the play, of which mock impoliteness is the most frequently used strategy. Concerning the response strategies, the defensive and defensive-offensive strategies are frequently used by the characters in Hamlet, but the most frequent one is the defensive strategy. These impoliteness strategies and their responses have adversely affected the relationship amongst characters in the play and its general atmosphere.
\end{abstract}

Keywords: Impoliteness, Impoliteness Strategies, Response Strategies, Speech Acts.

\section{Introduction}

As a non-marginal human linguistic phenomenon within certain types of discourse, impoliteness is roughly defined as confrontational conflictive "communicative strategies designed to attack face, and thereby cause social conflict and disharmony" (Culpeper et al. 2003, 1546). However, pragmaticians and sociolinguists have largely ignored impoliteness since they have been mainly concerned with collaborative or supportive illocutions since 1973, whereby linguistic expression and communication of politeness are extensively investigated (Rudanko 2006; Bousfield 2008). More specifically, all the leading

() 2022 JJMLL Publishers/Yarmouk University. All Rights Reserved,

* Doi: https://doi.org/ 10.47012/jjmll.14.1.5

* Corresponding Author: abeeid@yahoo.com 
politeness theories mention the notion of impoliteness, but they all focus solidly on politeness and, accordingly, their comments on impoliteness are descriptively inadequate and often conceptually biased (Culpeper et al., 2003; Culpeper et al., 2017). Additionally, current approaches to politeness have been unable to fully account for the confrontational interaction in impolite discourses. Clearly, then, some sort of framework is needed to account for such linguistic behavior (Bousfield 2008, 71).

One of the most important and early accounts in this regard was the study of Brown and Levinson (1987) where "politeness was conceptualized as a particularized implicature, providing a face-related explanation of why the speaker chose to phrase her utterance the way she did in the context at hand" (Culpeper et al., 2017, 23). However, Brown and Levinson's study seems to be inadequate to account for conflictive discourse for the "methods of analysis [by Brown and Levinson] were not developed for the systematic, sequential interpretation of ongoing discourse. All of the examples given by Brown and Levinson are single utterances drawn out of the context of ongoing discourse" (Penman 1990, 16). More to the point, despite Brown and Levinson's $(1987,61)$ assertion that "it is in general in every participant's best interest to maintain each other's face", it is obvious that, in certain contexts, "displaying skills in formulating and sustaining disagreements is an interactional requirement that contributes to the interactants' positive self-presentation" (Patrona 2006, 2127, cited in Hanlon 2010, 1).

This interactional requirement is normally exploited in the use of impoliteness as in the case of army training camps (Culpeper 1996, see Kantatra 2010), to elicit truth as in the case of the American adversarial system (Lakoff 1989), amongst friends due to close relationships (Culpeper 1996; Kantara 2010), in doctor-patient discourse (Mehan 1990), and in workshop discourse (Anderson and Pearson 1999).

However, as Culpepper $(1996,364)$ states, "no study has systematically described the occurrence of impoliteness in drama or attempted to explain its importance". Hence, this study is hoped to be of significance because, despite the fact that Shakespeare's Hamlet has always been a focal point for the world researchers where it has been studied from various standpoints, impoliteness in Hamlet seems to have not been examined yet.

In light of this, the study attempts to examine impolite speech acts (ISAs), in Hamlet, along with their verbal responses. Specifically, the study is more concerned with the ISAs Hamlet often uses in his encounters with certain characters in the play, namely, his uncle, mother, Ophelia, Polonius, Rosencrantz and Guildenstern. Additionally, this study examines how these offended characters respond to Hamlet's intended offensive behavior and it is aimed to account for the potential reason(s) behind using these strategies in the given context, namely Hamlet's confrontations with the said characters in various contexts. The study is hoped to systematically account for the frequency, employment and the functions of both the ISAs and the response strategies (RSs). Most importantly, the influence of the related context on the pragmatic interpretations of both the ISAs and RSs is meticulously investigated. 
Pragmatic Analysis of Impolite Speech Acts and their Verbal

Responses in Shakespeare's Hamlet

\section{Literature Review}

Culpeper (1996) states that politeness is more concerned with when a given addressor highly considers his/her addressees face wants. In the other extreme, impoliteness ensues when the addressor intends to threaten these wants. It is evident, then, that politeness and impoliteness are quite interrelated for the latter is described as the opposite of the former and even the parasite of it (Culpeper 1996; Kantara 2010). Accordingly, the paradox in this area lies in that the models and approaches, which have evolved to account for and explain impoliteness, have already "evolved out of the existing approaches which were originally developed for politeness" (Bousfield 2008, 43). On this basis, the peculiar nature of impoliteness, the strategies employed to achieve impoliteness, the disharmony it causes and the intentions behind using impoliteness have almost all been overlooked. In what follows: the key notions of this study, namely, impoliteness, power, face, intentionality, impolite strategies (ISs) and response strategies (RSs), are examined in the light of the current studies in this area.

\section{Impoliteness}

Impoliteness can be crudely defined as the communicative behavior that results in social disharmony and promotes threats to the addressee who, sometimes, tends to respond in the form of a defensive or offensive manner (Bousfield 2008). It is obvious that impoliteness can take place when interlocutors are involved in a conflictive non-socially-cooperative discourse (Culpeper et al. 2003). Impoliteness is, therefore, intended to damage the person's identity and face (Culpeper 2005). Besides, impoliteness is viewed in a different way for it is not regarded as the opposite of politeness since they both can be handled, by an interlocutor, using 'the same analytical concepts' (Mills 2009). It is sometimes so difficult to accurately draw boundaries between politeness and impoliteness. However, impoliteness in an actual exchange occurs when (1) the speaker communicates a face-attack intentionally, or (2) when the hearer perceives and/constructs behavior as intentionally face-attacking, or (3) a combination of (1) and (2) (Culpeper 2005, 38).

In addition, Murphy $(2014,16)$ posits that impoliteness is a "negative (linguistic) behavior which is interpreted by the hearer to be an attack on his/her face. The speaker exacerbates and makes (very) salient this face-attack in his/her utterance. That attack on the hearer's face causes the hearer offence". As compared to politeness, impoliteness includes certain concepts, namely, overlap, rudeness, aggression, interruption. These concepts result in violations of the norms which interlocutors are expected to follow in the concerned situational and socio-cultural context (Culpeper et al. 2003). Impoliteness, as Al-Dilaimy and Khalaf (2015) stress, is reflected clearly in the interlocutor's verbal and non-verbal behavior in that they could express their impolite behavior through certain facial or hand movements or some other paralinguistic features. They, following Mills (2009), add that interlocutors can express their aggressive and impolite behavior via utilizing some words and utterances, such as abusing, cursing, reproaching, insulting, or threatening (Al-Dilaimy and Khalaf 2015).

However, the degree of impoliteness might vary from one situation to another. It can be noted that 'aggravated impoliteness' and the notion of impoliteness are distinguished via considering that a rude 
expression occurs on a 'scale' of impoliteness in which 'aggravated impoliteness' is "the high end of the impoliteness scale or continuum" (Rudanko 2006, 836 see Culpeper et al. 2003). In this respect, the offensiveness of harsh expressions used in a given confrontation is based on their cultural connotations, the relationship between interlocutors, denotative meanings, and the language preceding and following them (Migdadim Badarneh, and Abbas 2013). Most importantly, Culpeper et al. (2017, 29) state that "context is all important to assessments of (im)politeness. Even a bare imperative directive Shut up can be polite, if said slowly and evenly with a kind tone of voice to one's chatty sweetheart while gazing at the moon". Thus, the highest and lowest scale of impoliteness is well illustrated in the different ways according to which an essay, for instance, is criticized as follows (Culpeper 1996, 85):

It wasn't good.

It was bad.

It was crap.

You must have shit for brains.

The above utterances are ranked on a scale "from very polite to very impolite" (Culpeper 1996).

\subsection{Impoliteness and Power Game}

Many sociolinguists and pragamticians have identified many reasons of why people behave impolitely in certain kinds of discourse. For instance, Culpeper (1996) believes that the main reason behind impoliteness is a personality trait in addition to other reasons including power for the more powerful participant tends to be impolite in the game of 'imbalance of power'. Culpeper $(1996,354)$ has plainly stated that:

A powerful participant has more freedom to be impolite because he/she can (a) reduce the ability of the less powerful participant to retaliate with impoliteness, e.g. through the denial of speaking rights and (b) threaten more severe retaliation should the less powerful participant be impolite.

Furthermore, conflict of interest is another reason in institutionalized settings; some participants think that it is not in their interest to maintain the other's face. Accordingly, they try to gain a long-term interest via utilizing some impoliteness strategies, as illustrated in the use of impoliteness in the army training camps (Culpeper 1996, see Kantara 2010).

Alternatively, Lakoff (1989, 307, cited in Kantara 2010) asserts that "impoliteness may be employed as a means to achieve a particular goal by attacking the other's face, as is the case with the American adversarial legal system, where it is assumed that direct confrontation will elicit the truth". In the same relationships, as Culpeper $(1996,354)$ points out, impolite behavior occurs partly due to extremely intimate relationships. Specifically, in such kind of relationships there is always more space for impoliteness for one may better know the sensitive aspects of his addresses' face to attack, and "one may be able to better predict and/or cope with retaliation that may ensue". In the same vein, Kantara (2010) believes that impoliteness is often employed in intimate relationships since the more intimate the relationship, the more impoliteness one employs considering the relationship as a power game. Moreover, 
Pragmatic Analysis of Impolite Speech Acts and their Verbal

Responses in Shakespeare's Hamlet

the interlocutors' momentary emotional state plays a major role in the way they assess a given utterance as polite or not. Specifically, there is evidence that the speaker's negative emotional state, as being annoyed by the addressee, leads to a face-threating intention on the part of the speaker (Vergis 2015).

With all this in mind, the notion of power can be better defined and well perceived in what Kantara (2010, 307), based on Spenser-Oatey (2002), states as:

An individual A possesses legitimate and expert power if s/he has the freedom of action to achieve the goals s/he has set for him/herself, regardless of whether or not this involves the potential to impose A's will on others to carry out actions that are in A's interests, to which the others may not object.

Examples of legitimate and institutionalized use of power game are well illustrated in army training (Culpepper 1996), courtroom discourse (Lakoff 1989; Penman 1990), doctor-patient discourse (Mehan 1990), workshop discourse (Anderson and Pearson 1999). In all these institutionalized asymmetrical relationships, impoliteness is employed for a legitimate purpose (Schnurr, Marra and Holmes 2008).

In the analytical framework of this study, the notion of power is meticulously considered in examining the selected data. Being the prince of Denmark, Hamlet possesses legitimate power over most of the characters he interacts with. Consequently, the relationship Hamlet has with the other conversational characters seems asymmetrical since most of them are in a less powerful position, especially, Polonius, Ophelia, and Rosencrantz.

\subsection{The Notion of Face}

In pragmatics, face is one of the key notions that requires revisiting and better perceiving. As early defined by Goffman, 'face' refers to "the positive social value a person effectively claims for himself by the line others assume he has taken during a particular contact; [it is] an image of self-delineated in terms of approved social attributes" (1967, 5). Based on Goffman (1967), Brown and Levinson (1987) view 'face' as including two kinds of desires (face wants), namely, positive face and negative face where the former is about coming together and belonging, whilst the latter concerns avoiding contact and separation (O'Driscoll 1996, cited in Hanlon 2010, 2). Notably, they make a distinction between these two face wants where negative face refers to "the desire to be unimpeded in one's action" (Brown and Levinson 1987, 13). Brown and Levinson's addition of the notion of 'negative face' is considered a departure from Goffman's notion of face as an image of Self in relation to Other's evaluation (Hanlon 2010). However, some scholars believe that the positive/negative face distinction is unneeded to understand (im)politeness for such a dualism of face is quite vague (O'Driscoll 1996, cited in Hanlon 2010; Bousfield 2008b). Furthermore, the notion of face seems to be more concerned with the relationship between the interactants than with an individual's self-image co-constructed by interactants (Hanlon 2010). Similarly, utterances, as Mills $(2009,1049)$ points out, indicate "the degree of solidarity and friendship between interactants, and the relative status". Accordingly, the notion of face is well understood when the relationship between interactants is seriously taken into account since face is more associated with personal/social value and is more about people's sense of worth, credibility, dignity, honor, reputation, competition and so on 
Salman, Al-Saidi, khalaf

(Spencer-Oatey 2002, 540). In this context, Spencer-Oatey's (2002) notion of 'social identity' is more helpful, where she states that the fundamental desire, in the notion of face, is our need for people to acknowledge and uphold our social identities or roles, e.g. as group leader, valued customer, or close friend. Social identity face is concerned with the value that we effectively claim for ourselves in terms of social or group roles, and is closely associated with our sense of public worth (Spencer-Oatey 2002).

It is worth noting that certain communicative acts, namely, ordering, asking and commanding, are considered as face-threatening for they inherently threaten the other interlocutor's face wants (Al-Dilaimy and Khalaf 2015). This poses a problem when contexts such as army recruit training are considered since, in such contexts, face-attacking discourse is deemed basic and normal (Culpepper 2008). Nonetheless, such intentionally face-attacking utterances are marked regardless of their appropriateness "just because something is sanctioned does not mean impoliteness is neutralized for all participants ${ }^{\text {ee }}$ (Culpepper 2008, 40, see Bousfield 2008).

\subsection{Intentionality}

According to Grice (1978), the distinction between semantics and pragmatics is understood through conceiving that semantics is more about what is said by a certain speaker (truth-conditional content) whereas pragmatics is more concerned with what the same speaker intends (non-truth-conditional) in a given context (see Leech 1983). Grice also asserts that 'what is intended', rather than just 'what is said', is what determines the intended meaning of an utterance. More to the point, this reference to the knowledge of intentions is identified as pragmatic competence, which is the ability to explain people's behavior by ascribing intentions to them (Recanati 2010, 2, cited in Khan and Bughio 2012, 27). In terms of interlocutors' intentions, Goffman $(1967,14)$ asserts that threats to face are of three levels, namely, accidental, intentional and incidental where the first level is associated with 'unintended and unwitting utterance', the second is performed 'maliciously and spitefully', whereas the third level arises as "an unplanned but sometimes anticipated by-product of action". In the same context, hostile and aggressive behaviors are more severe since they are more marked and provoke negative emotion; they are more likely responded to by the addressee if they are perceived intentional (Culpeper 2008, 32).

Admittedly, a speaker's actual intention cannot be easily predicted or retrieved but can rather be reconstructed relying on such features attributable to communicative events such as "past encounters, knowledge of social roles and so on" (Mooney 2004, 901). Other features include the interlocutors' discourse roles, the context, the co-text, the activity type, previous events, effects between interactants, the power, rights and obligations of the interactants (Bousfield 2008, 74, see also Haugh 2007b, 93, Culpeper et al. 2017, 27). As identified above, only the interlocutor's intention can decide to what extent a given utterance is impolite or not for it largely depends on the speaker's intention, to harm, and the hearer's perception and understanding of the speaker's intention in addition to the relationship between them (Kantara 2010; Migdadi et al. 2013). In relation to this, it is highly significant to reconsider Grice's cooperative principle for it is misinterpreted in conflictive contexts due to the clash between Grice's use of the general and the technical meaning of the term 'cooperation' (Davis 2007). In other words, 
Pragmatic Analysis of Impolite Speech Acts and their Verbal

Responses in Shakespeare's Hamlet

interactants cooperate even if they disagree for "one needs to be cooperative, in a linguistic sense, in order to communicate a lack of cooperation in a social sense" (Bousfield 2008b, 29).

\subsection{Lachenicht (1980) Aggravating Language}

Both Lachenicht (1980) and Culpeper (1996) base their frameworks of impoliteness on Brown and Levinson's model of politeness as the underlying point of departure for their own work. Lachenicht (1980) referred to impoliteness as "Aggravating language" which is the means by which one can attack the interlocutor's face by insulting and using rude language. Accordingly, Lachenicht (1980) suggested four strategies of "aggravation"; "off-record aggravation" (such as implied insults, ambiguity, and irony), "bald on record" including both face threatening acts and interruption in an indirect way, positive aggravation (by making the interlocutor not accepted to be part of a specific group), and finally "negative aggravation" is used to impose the interlocutor, disturb his or her freedom, and to damage the position of the hearer in the society. As can be seen, the first two strategies reckon Brown and Levinson's (1987) politeness framework. Positive aggravation and negative aggravation can be differentiated with respect to their orientation to positive and negative face wants in that framework (Brown and Levinson 1987). Lachenicht argues that 'aggravated language' is employed to 'Hurt' the addressee. 'Hurt', according to Lachenicht $(1980,607)$, is achieved by (a) conveying that the addressee is not liked and does not belong and by (b) interfering with the addressee's freedom of action. However, Lachenicht (1980) does not consider silence or 'opting out' (Grice 1975) as a possible strategy to aggravate or 'hurt' the addressee. On the other hand, he $(1980,619)$ conceives off record strategies to be used against more "powerful addressees, positive aggravation against friends and intimates and negative aggravation against those more socially distant" (Bousfield 2008, 84).

\subsection{Culpeper's Strategies of Impoliteness}

Built against the politeness strategies of Brown and Levinson (1987), Culpeper's (1996; 2003; 2008; 2017 ) is the most widely common model of impoliteness. This model is based on a corpus of quite tensed exchanges, i.e. military training, exchanges between car owners and traffic wards, exploitative TV programs, and some drama dialogues (Bousfield 2008; Migdadi et al. 2013). According to this model, any communication act usually includes informational and interpersonal domains whereby the interpersonal platform often determines whether such a social behavior is polite or impolite (Culpeper et al. 2017).

However, studying impoliteness in equal relationships is much more difficult for each verbal attack can lead to a counterattack or even a physical attack. To reiterate, equal participants have more freedom to retaliate than unequal participants. Furthermore, Culpeper et al. (2003) assert that understanding impoliteness requires moving beyond the single strategy by considering the extended discourse and examining the role of prosodic features in conveying and emphasizing impoliteness. This extended model is formulated by Bousfield (2008) to work in other context types, namely, recordings of televised material that include reprimands in army training interactions, confrontations amongst car owners and with police wardens, and disputes between employees in a restaurant kitchen. 
Culpeper's (1996/2017) model consists of five strategies as follows:

1. Bald on Record Impoliteness: Impolite utterances are usually direct, unambiguous and concise where the speaker's real intention is to attack the face of the hearer.

2. Positive Impoliteness: The speaker intends to damage the hearer's positive face want (his/her want to be highly considered and appreciated).

3. Negative Impoliteness: This strategy is designed to damage the addressee's negative face wants (his/her want not to be imposed on).

4. Sarcasm or mock politeness: This is performed via the use of insincere politeness strategies by way of implicature (off-record impoliteness).

Sarcasm or mock politeness is largely built on Leech's (1983) notion of indirectness that in certain cross-cultural contexts, indirectness may be more impolite than directness where the former can increase impoliteness instead of promoting politeness (Culpeper, et al. 2003/2017). This strategy works by highlighting the discrepancy between the semantic meaning of the speaker's utterance and what is intended by the speaker, or how it is generally interpreted in such contexts (Culpeper 1996). It is noteworthy that sarcasm and off-record impoliteness often overlap with each other to the extent that it is difficult to make a clear-cut distinction between them (see Eisterhold, Attardo and Boxer 2006).

5. Withhold politeness: Not performing politeness work where it is expected.

In addition, Culpeper $(1996,357)$ suggests both positive and negative impoliteness output strategies as follows; (see Mirhosseini, Maryam and Hamidreza 2017, 223).

\section{Positive impoliteness output strategies:}

(a) Ignore, snub the other: fail to acknowledge the other's presence

(b) Exclude the other from an activity

(c) Disassociate from the other: for example, avoid sitting together

(d) Use inappropriate identity markers: for example, use title and surname when a close relationship pertains, or a nickname when a distant relationship pertains.

(e) Use obscure or secretive language

(f) Seek disagreement, like selecting a sensitive topic

(g) Make the other feel uncomfortable

(h) Use taboo words, like swearing

(i) Call the other name

Negative impoliteness output strategies are classified by Culpeper (1996, 3580) as follows (see Kantara, 2010, 311):
(a) Frighten
(b) Condescend, scorn or ridicule, emphasize your relative power
(c) Invade the others space-literally or metaphorically
(d) Explicitly associate the other with a negative aspect
(e) Put the other's indebtedness on record 
Pragmatic Analysis of Impolite Speech Acts and their Verbal

Responses in Shakespeare's Hamlet

It is important to highlight two other points relevant to Culpeper's ISs detailed above. Firstly, Culpeper et al. $(2003,1559)$ referred, in their data, to a further IS labeled 'to challenge' (negative impoliteness strategy), where the speaker often employs using a rhetorical question. Secondly, they assert that impoliteness does not simply result from one particular strategy but can be used in combination with other strategies, termed multiple strategies.

\subsection{Bousfield's Response Options Model}

Although Bousfield (2008) has also proposed his own model of impoliteness strategies, he is mostly cited for the responses he proposed for the impoliteness acts. Having modified and expanded Culpeper et al. (2003) remarks, Bousfield (2008) states that there are many response options available to recipients of face threats or attacks. Hence, when faced with an offensive act, recipients have many options as illustrated in Figure (1) below:

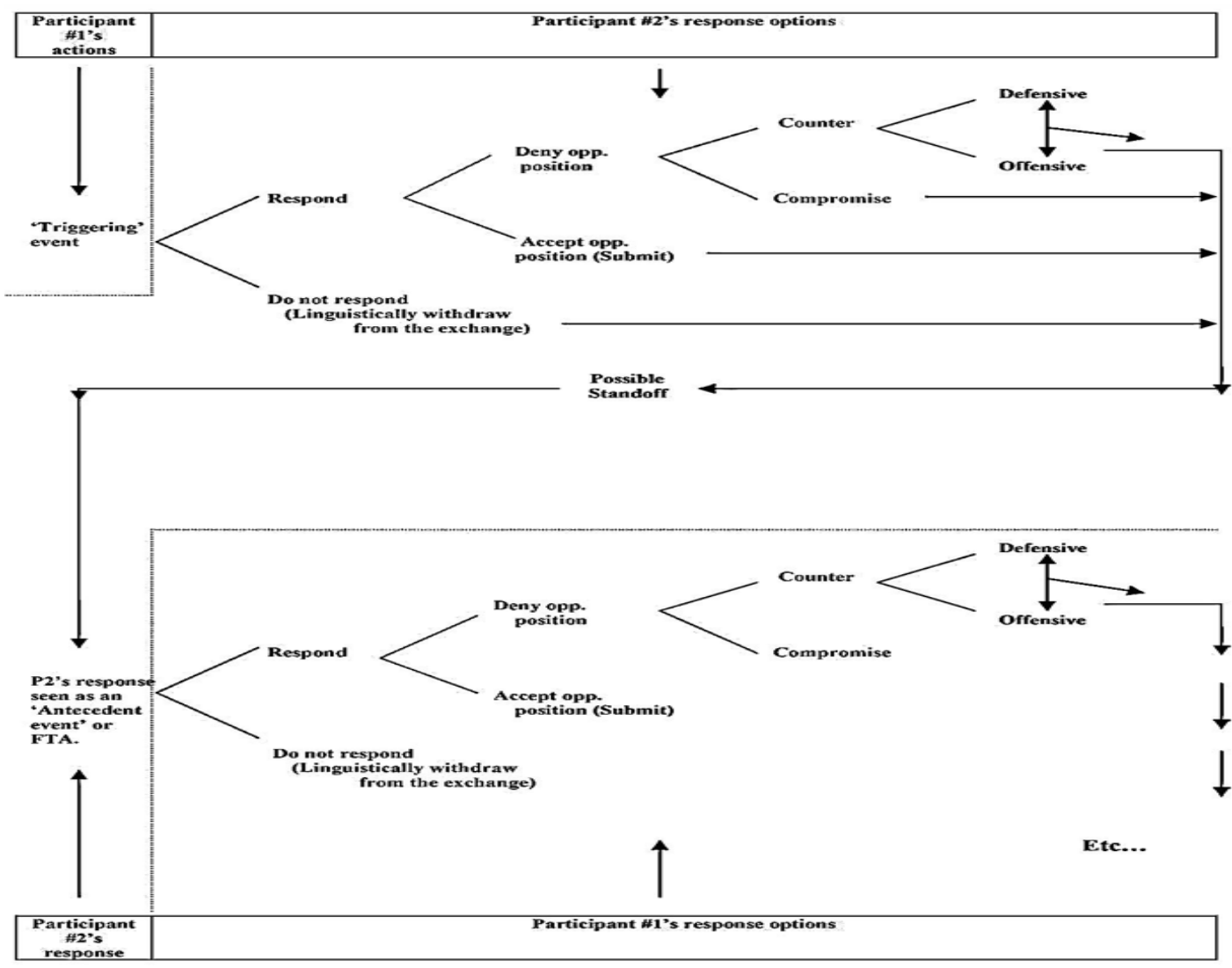

Figure 1: Bousfield's response options model (Bousfield 2008, 219).

In more detail, when recipients are faced with FTAs, they either respond or do not respond. If they choose not to respond, they will remain silent. However, keeping silent may indicate the following meanings: (a) they may be playing dumb, or (b) not knowing how to defend themselves (c) some, by staying silent, would accept the FTA, or (d) think of how to defend themselves (Bousfield 2008, 188, see Jan and How 2015). In certain cases, recipients of an offense might stay silent since the meaning entailed 
by an utterance is either unclear or inaudible when spoken (Bousfield 2008, 190). In other cases, offended recipients think that it is better to stay silent to avoid more conflict, especially when there is unbalance in power positions, i.e., when they face a superior and they are assumed as accepting the offending act (Bousfield 2008, 191). Sometimes, they choose not to respond not by keeping silent but rather by physically withdrawing, leaving the exchange to end the argument (Bousfield 2008, 215).

On the other hand, recipients who choose to respond will either accept or counter the FTA. In case they accept the face attack, they either agree or take the blame or even apologize and this kind of respond worsens their FTAs (Bousfield 2008, 193). When they opt for countering a face attack, their response will be either offensive or defensive or in pairs of offensive-offensive or offensive-defensive strategies (Bousfield 2008, 193). More specifically, those recipients who resort to the offensive-defensive strategy often tend to defend their own face via;

(1) Offering an account or explaining one's action

(2) Ignoring FTA

(3) Abrogation

(4) Stand-off

Elaborating on cases like these, Bousfield $(2008$, 195) points out that recipients who choose the offensive-defensive strategy attempt to detect or block to reduce their face damage and even tend to abrogate the exchange by switching roles and avoidance of the responsibility for causing the offence so as to save face. They also tend even to ignore the face attack as a defensive strategy when they try to respond positively or express insincere agreement, usually as a response to sarcasm. This often happens when the power positions are unequal (Bousfield 2008, 197). Similarly, recipients sometimes respond in a defensive way by offering an account or explaining one's action by denying the responsibility or providing excuses. They also use pleading as a defensive strategy by responding with politeness strategies such as 'please don't do this to me or cry' to seek the offender's sympathy (Bousfield 2008, 200, see Jan and How 2015, 91). In certain contexts, recipients tend to use the offensive-offensive strategy by countering a face-attack with a counter face-attack. This usually occurs among interlocutors of equal social or power positions (Bousfield 2008, 200, see Jan and How 2015, 91).

When applied to Hamlet, all the response strategies detailed above, namely, keeping silent, accepting face attack by agreeing or apologizing, countering face attack with another face attack, explaining one's action, ignoring FTA, abrogating and standing off, seem to work well in exchanges amongst characters in this play.

\section{Methodology}

\subsection{Research Approach and Data of the Study}

This study is qualitative in nature and, in particular, descriptive. It is mainly based on text analysis of the data collected, which reflects the pragmatic meanings and functions embodied in the use of the ISAs, used by Hamlet, and their responses which constitute the core unit of analysis in this study. Hence, the data comprise 32 of Hamlet's ISAs in addition to their responses (see the appendix below). Only 15 
Pragmatic Analysis of Impolite Speech Acts and their Verbal

Responses in Shakespeare's Hamlet

representative examples are randomly selected for analysis and interpretation to examine how ISAs are used by Hamlet and the response options available to the offended characters.

\subsection{Data Identification and Criteria for Selection}

The data collection of the study involved the following steps:

First, reading Hamlet in its original language from end to end to sort out the examples that display impoliteness to be hand-picked. Secondly, the RSs were identified in the selected dialogic exchanges. Thirdly, after collecting and classifying the data, samples that seem more typical and representative for the analysis in this study have been selected. The main criterion in this selection process was that the selected ISAs were replete with a high degree of offensiveness to the characters targeted. Thus, the use of those ISAs has its negative impact in shaping the relationship between Hamlet and any of the main characters involved.

\subsection{Data Analysis and Interpretation}

The data analysis is carried out in accordance with the research objectives and in the light of the theories adopted. On this basis, Culpeper's (1996-2003/2008/2017) and Bousfield's (2008) models have been utilized in this paper with the aim to pragmatically analyze the impoliteness strategies used by Hamlet and their responses in terms of the linguistic expressions used and the meanings and functions intended.

\section{Results and Discussions}

The discussion in this part is mainly concerned with the selected ISAs used by Hamlet in his dialogical exchanges with: (a) his most hated enemies, namely, his uncle and Polonius, (b) his friends Rosencrantz and Guildenstern, (c) His most loved two women, i.e. his mother-Gertrude and his belovedOphelia. In addition, the RSs these characters resort to in response to Hamlet's FTAs are also examined.

\subsection{Hamlet's Exchanges with Claudius and Polonius}

Hamlet's dialogues with his uncle and Polonius, Wang (2011) states, are full of puns, irony and paradoxes. This indicates that he not only tries to avoid communicating with them but also bitterly satirize them. Furthermore, his relation with these characters is highly tensioned to the extent that most of his talks with them are replete with so harsh words and expressions (Wang 2011, 695, see Hooper 2003 and Liu 2016). Consider the following extracts:

\section{Extracts (1-2)}

Claud:: But now, my cousin Hamlet, and my son

Ham: [Aside.] A little more than kin, and less than kind

Claud. How is that the clouds still hang on you?

Ham: Not so, my lord; I am too much i' the sun. (I.II.63-67). 
In this very early dialogical exchange in the play, Hamlet starts playing on the literal and metaphorical meaning of sun, which symbolizes authority (royalty), whereby it reflects the idiom "out of heaven's blessings into the warm sun". It may entail that Hamlet is disinherited from the Crown and is stepping into a much rough life after his father's sudden death (Liu 2016, 198). Similarly, by uttering "A little more than kin, and less than kind", Hamlet bitterly signifies that he and Claudius become closer relatives through incestuous marriage between the latter and Hamlet's mother, but they do not have the legal and natural paternity (Liu 2016; Hooper 2003; Basheer 2008). In the equable above, Hamlet announces a complex bundle of statement to his uncle: 1) He feels discomfort in the role of son to Claudius, and 2) He feels discomfort in the shadow of Claudius legal authority represented by the sun. Accordingly, he wants to implicitly tell the king that being "too much" in his presence results in disease and rottenness due to the latter's dangerous and poisonous influence (Hooper 2003). He intentionally utilizes the phonemic similarities between these words to "mock at what the king said to him... [they are] used as irony to satirize the king as hypocritical" (Liu 2016, 198). According to Altick (1954 cited in Hooper 2003), the sun is metaphorically used to refer to the 'powerful agent of corruption where Hamlet is characterizing the king as the vast influence of evil and corruption. Additionally, Hamlet "satirically attacks Claudius's claim that the prince is both his 'cousin' (i.e. kinsman) and his "son". In this way, Hamlet immediately establishes his role as a bitter court jester exposing the hollowness of political talk (Draudt 2002, 78; Omar and Khalaf 2008). Moreover, Hamlet seems to skilfully employ a multiple level of communication since he not only evades Claudius's trap but he also "delivers a multiple insult which... Claudius cannot answer" (Hooper 2003, 122).

In this encounter with the king, Hamlet employs multiple impoliteness strategies, i.e. positive impoliteness and sarcasm whereby, according to the former, Hamlet intends to damage the hearer's positive face wants by dissociating and/or excluding him from an activity (excluding him from both legal authority and natural paternity). In the latter, Hamlet employs insincere politeness by way of implicature to indirectly scorn, ridicule and associate the king with negative aspects. In response, the king seems not to answer, i.e. he opts for not to respond to Hamlet's insults maybe because Hamlet is shielded by punning on language which makes it difficult for the king to determine Hamlet's real intention.

The utilization of these and other similar impolite speech acts by Hamlet when addressing Claudius indicates clearly that his relationship with the latter is quite unhealthy. It indicates, moreover, a lack of harmony and understanding between these main characters in the play. As for Hamlet, such impolite speech acts represent a dramatic technique that is meant to reflect how shaky Claudius's character is! And since Hamlet considers Claudius the main source of his grief and sorrow, almost all his encounters with the latter are replete with such impolite speech acts. They are meant to show how hostile and vindictive Hamlet is towards Claudius. On his part, Claudius attempts to evade subsequent encounters with Hamlet in an attempt to avoid the latter's severe attacks resulting from these impolite speech acts. Extract 3 further illustrates this notion. 
Pragmatic Analysis of Impolite Speech Acts and their Verbal

Responses in Shakespeare's Hamlet

\section{Extract (3)}

Claud: : How fares our cousin Hamlet?

Ham.: Excellent i'faith, of the chameleon's dish, I eat the air; promise-crammed-you cannot feed capons so.

Claud.: I have nothing with this answer (III, II: 90-92).

Extract 3 represents another instance of Hamlet's utilization of impolite speech acts when addressing Claudius. In this extract, in response to the king's question, Hamlet utilizes sarcasm to mock the former's faked care and love. Specifically, via using "I eat the air ", Hamlet reveals that he is quite aware of Claudius's fake interest in him and how the new king has often lied to him. According to the implicature used, Hamlet compares his uncle's reality to the air since it lacks substance and actual sincerity. Accordingly, Hamlet mocks Claudius and accuses him as being hallow and insincere (Draudt 2002). The king's response indicates that Hamlet provides irrelevant answers to his question and the former feels offended since the latter attempts to fend off the King's question. Obviously, there seems to be a lack of communication between Hamlet and Claudius and this makes Claudius suspect Hamlet's intentions throughout the whole play (Wang 2011; Qasim et al. 2015).

The king resorts to the defensive strategy to guard against Hamlet's impolite answer by asserting that the latter's answer is irrelevant to the question raised. In most of his confrontations with the King, Hamlet intentionally employs the insincere politeness strategy and avoids using direct attack to the king because of the latter's powerful position. Obviously, the utilization of such impolite speech acts has been reflected on the interlocutors' relationship which is depicted as a sort of distrust, suspicion and even fear on the part of the King. Consider extracts 4 and 5 below;

\section{Extracts (4-5)}

Polonius: Do you know me, my lord?'

Hamlet: Very well. You are a fishmonger'.

Polonius: No, I'm not, my lord.

Hamlet: Then I wish you were an honest man'.

Polonius: 'Honest, my lord'? (Act II, Scene II: 523).

Contextually, the discrepancy of Polonius's appearance and his real nature as a hypocrite, opportunist and flatterer is exposed by Hamlet. (Draudt 2002, 74). Hamlet bitterly satirizes Polonius for his conspiracies by using the word fishmonger, as slang for 'pimp'- a man who is selling women for immoral purposes (Wang 2011, see Williams 2006, 126). Additionally, "the bawd sense is more appropriate when Hamlet describes Polonius as 'a fishmonger', whether or not he is aware of Polonius's insensitive manipulation of his daughter"(Williams 2006, 126). In brief, Hamlet deflates Polonius' self-esteem and dignity by accusing him of being so dishonest and immoral since he proves to be "lower than the lowest of the low, worse than the worst of bad" (Wang 2011, 696). 
In this encounter, Hamlet utilizes both sarcasm and the positive impoliteness strategies to abuse Polonius by making him feel uncomfortable through the use of secretive language and selecting a sensitive topic. In return, Polonius responds via using a defensive strategy by denying the offence once and by pretending not to understand Hamlet's intention, i.e. to infer what Hamlet means thinking that Hamlet is really mad (Basheer 2008). In terms of the interlocutors' relationship, Hamlet seems to severely criticize and even contemptuously mock Polonius via the use of these impolite speech acts. Hamlet fully utilizes his superior position and power which authorize him to use very offensive speech acts when addressing Polonius in an attempt to sketch the latter's character as being villain and contemptuous. On his part, Polonius, due to his inferior position, cannot retaliate using similar impoliteness strategies. Extract 6 further illustrates this point.

\section{Extract (6)}

Polonius: 'What is the matter, my lord'?

Hamlet: 'Between who'?

Polonius: 'I mean the matter that you're reading'?

Hamlet: 'Slanders,' 'For the satirical rogue who wrote this says here that old men have grey beards: that their faces are wrinkled, their eyes watery and sticky and that they are stupid.

Polonius: It was madness alright, but there seemed to be some sense in it somewhere.

In the above conversation, Polonius is inquiring about the book subject. In reply, Hamlet tells the truth that there are words in the book whereby the author abuses old men shamefully. Old men are described as having gray beards, wrinkled faces, and a plentiful lack of wit (Qasim et.al. 2015). Since Hamlet suspects a trick to be played on him, he deliberately makes his utterances vague so that Polonius cannot interpret their intended meaning (Basheer 2008, 52). Polonius seems unable to understand Hamlet's real message thinking that the latter is actually mad but Polonius admits that there is some sense in what Hamlet has conveyed.

In extract (6), Hamlet has employed the sarcasm strategy to abuse Polonius via ridiculing and associating him with negative aspects, namely, wrinkled face, watery and sticky eyes and witlessness. In response, Polonius seems to accept Hamlet's offensive utterances because he thinks that the former is mad. More importantly, Hamlet's employment of ISs and Polonius's responses indicate that their relationship is much tensioned for the same explanation presented in the discussion of extracts (4-5).

\subsection{Hamlet's Exchanges with Rosencrantz and Guildenstern}

Despite being Hamlet's classmates and friends, Rosencrantz and Guildenstern have openly sided with Claudius and willingly worked as spies to snoop on Hamlet. They have clearly shown disloyalty to the prince though he warns them not to interfere in matters they do not understand. Resultantly, they increasingly arouse the prince's scorn and contempt (Draudt 2002; Wang 2011). Consider extracts 7 and 8 below; 
Pragmatic Analysis of Impolite Speech Acts and their Verbal

Responses in Shakespeare's Hamlet

\section{Extracts (7-8)}

Hamlet.: Besides, to be demanded of a sponge! What replication should be made by the son of a king ?

Rosencrantz: Take you me for a sponge, my lord?

Hamlet.: Ay, sir, that soaks up the king's countenance, his rewards, his authorities.

Rosencrantz.: I understand you not, my lord (IV.II,11-22).

Ham.: I am glad of it: a knavish speech sleeps in a foolish ear. ?(IV.I).

Rosencrantz.: My lord, you must tell us where the body is.

In extract (7) above, Hamlet has rudely insulted Rosencrantz by describing him as a sponge, which labels him as falterer and sycophant in reference to his being Claudius's willing lackey instrument, who, like a sponge, takes whatever the king offers but then is dried by the king's authority (Draudt 2002). Using 'sponge' in reference to Rosencrantz, Hamlet wants to state that although Rosencrantz is now soaking up the king's favor and rewards, when the king is done with him, he will squeeze him dry. Rosencrantz replies that he does not understand but he is probably lying because Hamlet's message is quite clear. Hamlet has been insulting Rosencrantz twice by describing him as having a foolish ear since the latter seems not to realize what Hamlet intends to indirectly convey (Niazi 2008; Mirdas 2016).

By way of implicature, Hamlet insincerely uses indirectness, as a form of (im)politeness, to ridicule and scorn Rosencrantz via associating him with a negative activity, i.e. being falterer. Rosencrantz seems to realize Hamlet's message and responds by a defensive RS -I understand you not, my lord - through denying what Hamlet claims of him but he ignores Hamlet's last offense. The use of such ISs indicates that Hamlet's relationship with both Rosencrantz and Guildenstern echoes a great deal of mistrust and uncertainty, particularly, due to his belief that they have been sent by the king as spies. Accordingly, the solidarity relationship between Rosencrantz and Guildenstern on the one hand and Hamlet on the other has changed into a disloyal one. However, their past good friendship gave Hamlet the liberty to criticize his old friends in this manner. Extract 9 is also typical of this notion.

Extract (9)

Hamlet.: Will you play upon this pipe?

Guildenstern.: My Lord, I cannot.

Hamlet: I pray you.

Guildenstern: Believe me, I cannot.

Hamlet: It is as easy as lying.

Guildenstern: But these cannot...; I have not the skill. (III. II, 343-351)

Aftermath the play within a play, Guildenstern and Rosencrantz have been trying their best to uncover the source of Hamlet's madness. The irony here lies in the fact that while they talk to Hamlet as if he were a child, he is quite aware of their plans and that they work as spies for Claudius (Draudt 2002).

In this exchange, Hamlet surprises and challenges Guildenstern when asking the latter if he can play upon a pipe-: "Will you play upon this pipe?" While the former has repeatedly urged the latter to play the pipe, the latter has often shown inability to perform arguing that he does not have the skill required. At 
this point, Hamlet has openly directed an offense to Guildenstern by declaring mockingly that playing (tricking) the pipe is as easy as lying. In other words, Hamlet wants to tell Guildenstern that only a talented person can play the pipe easily, and since the latter is untalented (lacking the deceptive skill) at playing the pipe, he is just untalented when it comes to lying (Draudt 2002).

In extract (9) above, Hamlet resorts to the bald-on record IS via directly describing Guildenstern as a liar since he hides his actual role as a spy on Hamlet for the king. In reply, Guildenstern chooses not to respond to Hamlet's offense maybe because Guildenstern cannot comprehend Hamlet's real intent. The above exchange reveals that the interlocutors' relationship has changed from friendship to a sort of animosity.

\subsection{Hamlet's Exchanges with Gertrude and Ophelia}

Based on the play, Hamlet seems to actually love and respect his mother and his beloved-Ophelia. His mother's hasty marriage to Claudius, which Hamlet views as disloyalty and a sort of betrayal, turns his love into a storm of rage and contempt. Similarly, his crazy love to Ophelia has become a heap of disregard and ridicule because she has been recruited by the king, the queen and Polonius to spy on him. Accordingly, when Hamlet talks with these two women, "he chooses the most brutal and rough language and even lots of disgusting words... Hamlet is trying to show his true feelings... he shows his displeasure of her [his mother] second disgraceful marriage. To Ophelia, Hamlet just wants to protect her to be away from this dangerous revenge" (Wang 2011, 696). Let us consider extracts 10 and 11:

Extracts (10-11-12)

Gertrude: Hamlet, thou hast thy father much offended.

Ham: Mother, you have my father much offended.

Gertrude: Come, come, you answer with an idle tongue.

Ham: Go, go, you question with a wicked tongue.

Gertrude: Why, how now, Hamlet! Have you forgotten me?

Ham: No, not so:You are the queen, your husband's brother's wife; Gertrude: Nay, then, I'll set those to you that can speak.

Via employing bald on-record impoliteness, Hamlet uses the same words his mother has utilized, namely, offend and tongue, but with meanings that skilfully express his state of mind. While the queen states that he has offended his father, meaning his stepfather, Claudius, he bluntly declares that she has offended his father, meaning the dead King by marrying Claudius. As she realizes his intention, she employs a defensive-offensive strategy by implicitly denying his offense and accusing him of being impolite with her by answering her question with such an idle tongue which he also turns to a mocking statement as she questions him with a wicked tongue. Then, he resorts to sarcasm to bitterly ridicule his mother by calling her as her "husband's brother's wife" (III.IV, 556). This implied offense in such a soft needle he masterfully utilizes to hurt her, which causes her to become outrageous and offends him in return by asserting that he is undisciplined and needs those who can stop him (Wang 2011).

In short, Hamlet has used two ISs, i.e. bald on-record and sarcasm where the first strategy is used twice while the second is used once. In response, the queen has utilized defensive-offensive RSs since the 
Pragmatic Analysis of Impolite Speech Acts and their Verbal

Responses in Shakespeare's Hamlet

prince and his mother are equal in power positions. In the above exchanges, Hamlet's words imply too much disappointment of and even contempt to his mother and this indicates that the son-mother relationship is much more unnatural.

\section{Extract (13)}

Hamlet: O shame! where is thy blush? Rebellious hell,

If thou canst mutine in a matron's bones,

To flaming youth let virtue be as wax,

And melt in her own fire.

Gertrude: O, speak to me no more, these words, like daggers, enter in mine ears.

This dialogical exchange (13) above occurs in the queen's closet, whereby Hamlet scolds his mother using very harsh terms for she has dishonored her first husband by marrying his brother. Hamlet almost becomes coarse and brutal in his language when he condemns his mother. But this is in accordance with his decision to "speak daggers" to her (Niazi 2008; Mirdas 2016). In this exchange, Hamlet employs the bald-on-record impoliteness strategy since he directly and baldly offends his mother addressing her "O shame! Where is thy blush". In return, his mother has employed two response strategies, i.e. accepting his offense by implicitly confessing her sin and defending herself by pleading via agreeing or taking the blame, a strategy which worsens her FTAs by requesting Hamlet to say no more offenses. The above exchange reveals that Gertrude-Hamlet relationship is over-tensioned.

\section{Extract (14)}

Ophelia: My lord, I have remembrances of yours that I have longed long to redeliver.

I pray you, now receive them.

Hamlet: No, not I. I never gave you aught.

Ophelia:: My honour'd lord, you know right well you did; And, with them, words of so sweet breath composed as made the things more rich: their perfume lost, Take these again; for to the noble mind. Rich gifts wax poor when givers prove unkind (III.I, 90-93).

According to the play, the King, the Queen and Polonius have often recruited Ophelia who allows herself to cooperate with them via spying on her previously-arranged encounters with Hamlet. Specifically, she renounces her love for Hamlet through reporting his behaviour in private and surrendering his love letters and poems to her father. As a result, Hamlet's love to her turns to misogynistic contempt since she obediently lets her father loose her to Hamlet as the honey-trap in a spy set-up (Lewin 2014). What makes things worse is that Hamlet is fully aware of the fact that his beloved attempts to uncover his secret.

In the above exchange, she has been directed to send him such a wrong and seemingly offensive message by giving him back the 'remembrances' he has already gifted her. He denies being the giver of such love-tokens using the word "aught" which means that he has never given her anything valuable or that he is no more the Hamlet she has known before (Basheer 2008). Hamlet is deeply wounded and terribly disappointed by her behavior. In the same encounter, she sends him a further offending massage when she says 'Rich gifts' wax poor when givers prove unkind'. Her responses worsen the scene since she 
has confirmed that he has actually given her the tokens, implying that he lies to her, and indirectly accusing him of being unkind to her.

In terms of ISs and RSs used, Hamlet has employed the positive impoliteness strategy through excluding and disassociating Ophelia and making her uncomfortable via not acknowledging their love relationship. In reply, she decides to encounter by denying his offenses via using defensive and sometimes offensive response options, particularly when she attempts to implicitly discredit the truthfulness of his love to her and even describing him as being 'unkind', which is quite offensive to a so romantic and highly affectionate prince like Hamlet. Accordingly, this indicates that the interlocutors' relationship is of bitter disappointment and despair.

Extracts (15)

Hamlet: I did love you once.

Ophelia: Indeed, my lord, you made me believe so.

Hamlet: You should not have believed me;...I loved you not.

Ophelia: I was the more deceived. (III.I, 114-135)

Hamlet: I have heard of your paintings too, well enough. God has given you one face and you make yourselves another.

Ophelia: Oh, dear God, please help him!

Hamlet continues offending Ophelia by way of the bald on-record impoliteness strategy declaring baldly that though he 'did love her once', he no longer loves her any more. In his utmost rage, Hamlet denies any love affair with her and says that 'I loved you not' (lines 127-128), Ophelia's replies that she was 'the more deceived' (line 129). In other words, Ophelia employs the offensive-offensive RS since she thinks that Hamlet has more disappointed her through cheating, i.e. showing her untrue and unreal love (Khan and Bughio 2012). Furthermore, Hamlet has utilized bald on-record impoliteness by attacking Ophelia directly discrediting her honesty by accusing her of having more than one face- 'God has given you one face and you make yourselves another'. Accordingly, he makes reference to her being hypocrite since she has betrayed him via siding her father and the king and providing them even with Hamlet's love letters just to enable them know his secret. In response, she seems not to communicate with him and therefore never understand his message thinking that he is really mad.

\section{Conclusion}

The analysis of the collected data revealed that the most frequently used impoliteness strategies are sarcasm and bald on record $(14,11)$ respectively. In addition, the findings of the study showed that the less frequent impoliteness strategy used by Hamlet is the positive impoliteness. As for the response strategies, the most frequent one is the defensive strategy (10), while the least used response strategies are compromise, no response, and offensive-offensive (2, 3, 3, respectively). The employment of the ISs has a strong effect on the interlocutors' relationship in that it makes some of them more defensive than others just to avoid confrontation with Hamlet. This is justified by having the defensive response strategy as being the highest (10). This response strategy is frequently repeated with only two impoliteness strategies, namely bald on record and sarcasm (4 and 6, respectively). These frequencies of impoliteness strategies and their responses are summarized in Table (1). 
Pragmatic Analysis of Impolite Speech Acts and their Verbal

Responses in Shakespeare's Hamlet

Table 1: Types and Frequency of Impoliteness Strategies and their Responses.

\begin{tabular}{|c|c|c|c|c|c|c|c|c|}
\hline \multirow[t]{3}{*}{ Strategies } & \multirow{3}{*}{$\begin{array}{l}\text { Tota } \\
1\end{array}$} & \multicolumn{7}{|l|}{ Responses } \\
\hline & & \multirow{2}{*}{$\begin{array}{l}\text { No } \\
\text { Response }\end{array}$} & \multicolumn{6}{|c|}{ Respond } \\
\hline & & & Accept & Compromise & $\begin{array}{l}\text { Defensiv } \\
\text { e }\end{array}$ & $\begin{array}{l}\text { Offensiv } \\
\text { e }\end{array}$ & $\begin{array}{l}\text { Offensive- } \\
\text { Defensive }\end{array}$ & $\begin{array}{l}\text { Offensiv } \\
\text { e- } \\
\text { offensive }\end{array}$ \\
\hline Bald on record & 11 & 0 & 1 & 1 & 4 & 2 & 2 & 1 \\
\hline $\begin{array}{l}\text { Positive } \\
\text { Impoliteness. }\end{array}$ & 7 & 1 & 1 & 1 & 0 & 1 & 2 & 1 \\
\hline $\begin{array}{l}\text { Negative } \\
\text { Impoliteness. }\end{array}$ & 0 & 0 & 0 & 0 & 0 & 0 & 0 & 0 \\
\hline $\begin{array}{l}\text { Withhold } \\
\text { Politeness }\end{array}$ & 0 & 0 & 0 & 0 & 0 & 0 & 0 & 0 \\
\hline $\begin{array}{l}\text { Sarcasm or } \\
\text { Mock } \\
\text { Politeness }\end{array}$ & 14 & 2 & 2 & 0 & 6 & 1 & 2 & 1 \\
\hline Frequency & 32 & 3 & 4 & 2 & 10 & 4 & 6 & 3 \\
\hline
\end{tabular}

The ISs mostly affected the relationship between Hamlet and all the other characters in the play, most importantly his mother, Ophelia, and his friends whom he used to trust. Consequently, the general atmosphere in the play becomes full of uncertainty, anger, and accusations which caused tension amongst the interlocutors. This is clearly shown in the frequent use of sarcasm as an IS by Hamlet and the types of response strategies employed by the interlocutors who are the targets of those ISs. It is obvious that the only person who has power over Hamlet is his mother, which is reflected by her utilizing of the offensive response strategy. All the other interlocutors mostly preferred not responding, defending their positions, or accepting the offense to avoid any confrontation with Hamlet. As a dramatic technique, the employment of these impoliteness strategies, specifically by Hamlet, has helped in making a character sketch of the interlocutors who are his normal targets. 


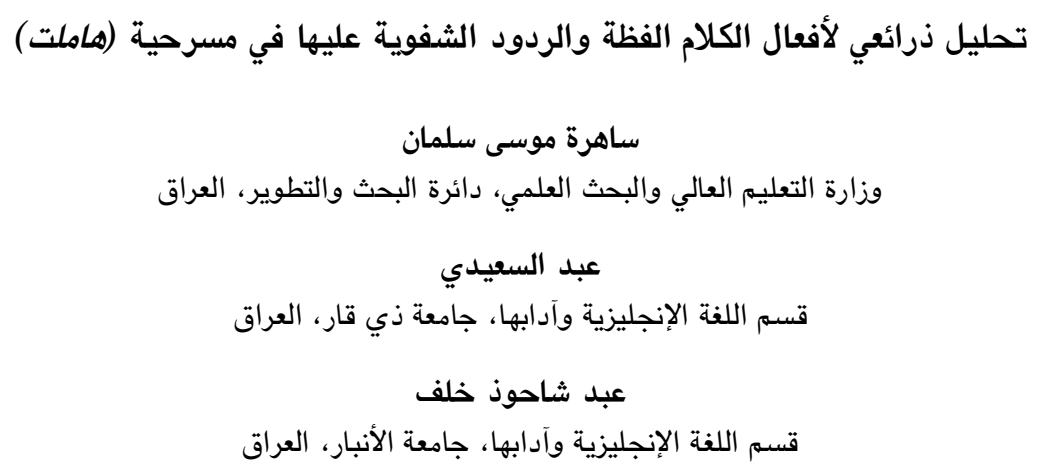

\section{الملخص}

تحاول هذه الدراسة إجراء تحليل ذرائعي لاستراتيجيات الفظاظة التي يوظفها هاملت في حواراته مع شخصيات المسرحية الأخرى. وتهدف الدراسة إلى تحليل ردود الشخصيات الأخرى الشفوية على أفعال الكلام الفظة التي يستخدمها هاملت لتحديد أي من استرتيجيات الرد كانت ترتبط بشكل متكرر أكثر مع أي من استرتيجيات الفظاظة. ولتحقيق هذه الأهداف، جمعت الدراسة 32 فعلاً كلامياً فظاً مع الردود عليها من مسرحية هاملت لتمثل مادة التحليل. ومن بين هذه الأفعال الكلامية، تم اختيار 15 مثالاً بشكل عشوائي لتحليل استرتيجيات الفظاظة باستخدام نموذج كلبر (2017/2011/1996) وكلببر وبوصفيلد ووتثمان (2003). وزيادة على ذلك، تم استخدام نموذج بوصفيلد (2008) في دراسة ردود المتحدثين على الفظاظة. وقد أظهرت نتائج الدراسة أن الفظاظة الوهمية، والفظاظة المباشرة، والفظاظة الإيجابية قد تكررت في المسرحية، وكانت الفظاظة الوهمية الاستراتيجية الأكثر استخداماً. وفيما يتعلق باستراتيجيات الرد على تعابير الفظاظة، كررت شخصيات المسرحية استخدام الاسترتيجيات الدفاعية والدفاعية - الهجومية، إلا أن الاستراتيجية الأكثر استخداماً كانت الاستراتيجية الدفاعية. لقد أثرت استرتيجيات الفظاظة تلك والردود عليها على العلاقة بين شخصيات المسرحية وعلى جوها العام بشكل كبير. الكلمات المفتاحية: الاستيعاب القرائي، المهارات الفرعية للاستيعاب القرائي، الخريطة الذهنية الإلكترونية، اللغة الإنجليزية كلفة 
Pragmatic Analysis of Impolite Speech Acts and their Verbal

Responses in Shakespeare's Hamlet

\section{References}

Al-Dilaimy, Hazim Hakkush, and Abed Shahooth Khalaf. 2015. A Pragmatic Analysis of Impolite Interruptions of Selected Debates in the Opposite Direction of Al-Jazeera Channel. American Journal of Educational Research 3 (12): 1570-1578.

Andersson, Lynne M., and Christine M. Pearson. 1999. Tit for Tat? The Spiraling Effect of Incivility in the Workplace. Academy of Management Review 24 (3): 452-471. DOI: 10.2307/259136 https://www.jstor.org/stable/259136 (accessed August 1, 2018).

Basheer, Sami Al Hasnawi. 2008. Lack of Coherence in Hamlet's Madness Scenes: A Pragmatic Analysis. Journal of Al-Qadisiya University 11 (4): 47-56.

Bousfield, Derek. 2008. Impoliteness in Interaction. Amsterdam: John Benjamins Publishing.

Bousfield, Derek. 2008b. "Impoliteness in the Struggle for Power". In Impoliteness in language: Studies on its Interplay with power in theory and practice, ed. Bousfield, Derek, and Miriam A. Locher., 127-53. The Hague: Mouton de Gruyter.

Bousfield, Derek, and Miriam A. Locher. 2008. Impoliteness in Language: Studies on its Interplay with Power in Theory and Practice. The Hague: Mouton de Gruyter.

Brown, Penelope, and Stephen Curtis Levinson. 1987. Politeness: Some Universals in Language Usage. Cambridge: Cambridge University Press.

Culpeper, Jonathan. 1996. Towards an Anatomy of Impoliteness. Journal of pragmatics 25 (3): 349-367. DOI: 10.1016/0378-2166(95)00014-3.

Culpeper, Jonathan. 2005. Impoliteness and Entertainment in the Television Quiz Show: The Weakest Link. Journal of Politeness Research. Language, Behaviour, Culture 1 (1): 35-72. DOI: 10.1515/jplr.2005.1.1.35.

Culpeper, Jonathan. 2008. "Reflections on Impoliteness: Relational Work and Power". In Impoliteness in language: Studies on its interplay with power in theory and practice, ed. Bousfield, Derek, and Miriam A. Locher, 17-44. Berlin: Mouton de Gruyter.

Culpeper, Jonathan. 2011. Impoliteness: Using Language to Cause Offence. Cambridge: Cambridge University Press.

Culpeper, Jonathan, Bousfield, Derek., and Wichmann, Anne. 2003. Impoliteness Revisited: With Special Reference to Dynamic and Prosodic Aspects. Journal of Pragmatics 35 (10-11): 1545-1579. https://doi.org/10.1016/S0378-2166(02)00118-2.

Davies, Bethan. 2007. Grice's Cooperative Principle: Meaning and Rationality. Journal of Pragmatics 39 (12): 2308-2331. https://doi.org/10.1016/j.pragma.2007.09.002.

Draudt, Manfred. 2002. The Comedy of Hamlet. Atlantis 24 (1): 71-83.

Eisterhold, Jodi, Salvatore Attardo, and Diana Boxer. 2006. Reactions to Irony in Discourse: Evidence for the Least Disruption Principle. Journal of Pragmatics 38 (8): 1239-1256. https://doi.org/10.1016/j.pragma.2004.12.003. 
Goffman, Erving. 1967. Interaction Ritual: Essays in Face to Face Behavior. London: Penguin Books.

Greatbatch, David. 1988. A Turn-Taking System for British News Interviews. Language in Society 17 (3): 401-430. URL: http://www.jstor.org/stable/4167953.

Grice, Herbert. Paul. 2008. "Further Notes on Logic and Conversation". In Reasoning: Studies of human inference and its Foundations, ed. Jonathan E. Adler and Lance J. Rips, 765-773. Oxford: Oxford University Press.

Grice, Herbert. Paul. 1975. "Logic and conversation.” In Speech Acts [Syntax and Semantics 3], ed. Peter Cole and Jerry Morgan, 41-58. New York: Academic Press.

Hanlon, Bernadette. 2015. Verbal Aggression and Neutrality in Political Interviews. Diffusion: The UCLan Journal of Undergraduate Research 3 (2): 1-17.

Hooper, Teresa. 2003. Dangerous Doubles: Puns and Language in Shakespeare's Hamlet'. Chrestomathy: Annual Review of Undergraduate Research at the College of Charleston 2: 120-134.

Jan, Jariah Mohd, and C. How. 2015. Discursive Construction of Asian Responses towards Impoliteness. Pertanika Journal of Social Scinces \& Humanities 23 (S): 89-106.

Kantara, Argyro. 2010. Impoliteness Strategies in 'House MD'. Lodz Papers in Pragmatics 6 (2): $305-$ 339. DOI: $10.2478 / \mathrm{v} 10016-010-0015-9$.

Khan, Qaisar, and Faraz Ali Bughio. 2016. Nunnery Scene: A Pragmatic Analysis of Hamlet-Ophelia Encounter. 3L: Southeast Asian Journal of English Language Studies 18 (2): 25-34.

Lachenicht, Lance. 1980. Aggravating Language: A Study of Abusive and Insulting Language. Research on Language \& Social Interaction 13 (4): 607-687.

Lakoff, Robin Tolmach. 1989. The Limits of Politeness: Therapeutic and Courtroom Discourse. Multilingua-Journal of Cross-Cultural and Interlanguage Communication 8 (2-3): 101-130.

Geoffrey, Leech. 1983. Principles of Pragmatics. London and New York: Longman.

Lewin, James. 2011. Hamlet's Hard-Boiled Ethics. "Ohio Valley Shakespeare Conference". The University of Akron, Ohio, USA. November, 2011, 23-37. Available at: https://ideaexchange.uakron.edu /spovsc/vol4/iss2011/3

Liu, Yi-Ling. 2016. The Translation of Puns and Allusions: A Case Study of the Chinese Translation of Shakespeare's Play Script on Hamlet. Translation Review 9 (2): 193-214.

Mehan, Hugh. 1990. "Oracular Reasoning in a Psychiatric Exam: The Resolution of Conflict in Language". In Conflict talk: Sociolinguistic investigations of arguments in conversations, ed. Allen D. Grimshaw 160-178. Oxford: Oxford University Press.

Migdadi, Fathi, Muhammad Badarneh, and Khaled Abu Abbas. 2013. Conflict Talk and Argumentative Strategies in Highly Adversarial Talk Shows: The Case of Al-Jazeera's The Opposite Direction. Lodz Papers in Pragmatics 9 (1): 93-121.

Mills, Sara. 2009. Impoliteness in a Cultural Context. Journal of Pragmatics 41 (5): 1047-1060. https://doi.org/10.1016/j.pragma.2008.10.014. 
Pragmatic Analysis of Impolite Speech Acts and their Verbal

Responses in Shakespeare's Hamlet

Mirdas, Sa'ad Abdullah. 2016. A stylistic study of irony in Shakespeare's Hamlet and Ben Jonson's Volpone. Unpublished thesis, Thi-Qar University, Iraq.

Mirhosseini, Monir, Maryam Mardanshahi, and Hamidreza Dowlatabadi. 2017. Impoliteness Strategies Based on Culpeper's Model: An Analysis of Gender Differences between Two Characters in the Movie Mother. Journal of Applied Linguistics and Language Research 4 (3): 221-238.

Mooney, Annabelle. 2004. Co-operation, Violations and Making Sense. Journal of Pragmatics 36 (5): 899-920.

Murphy, James. 2014. (Im)politeness during Prime Minister's Questions in the UK Parliament. Pragmatics and Society 5 (1): 76-104.

Niyazi, Saleem, trans. 2008. Hamlet the Prince of Denamrk by William Shakespere. Damascus: AlMada Publishng Company.

Omar, Zeydan. Khalaf. and Abed Shahooth. Khalaf. 2008. A Pragmatic Analysis of Hyperbolic Expressions in Shakespeare's Hamlet. Anbar University Journal for Humanities 3 (12): 498-509.

Penman, Robyn. 1990. Facework and Politeness: Multiple Goals in Courtroom Discourse. Journal of Language and Social Psychology 9 (1-2): 15-38.

Qasim, Naheed, Zainab Akram, and Hajira Masroor. 2015. Some Instances of Violation of the Maxims of Quantity, Relevance, and Manner by the Main Character (Hamlet) in Shakespeare's Play Hamlet. International Journal of Physical and Social Sciences 5 (5): 32-49.

Rudanko, Juhani. 2006. Aggravated Impoliteness and two Types of Speaker Intention in an Episode in Shakespeare's Timon of Athens. Journal of Pragmatics 38 (6): 829-841.

Schnurr, Stephanie, Meredith Marra, and Janet Holmes. 2008. "Impoliteness as a Means of Contesting Power Relations in the Workplace. In Impoliteness in language: Studies on its interplay with power in theory and practice, ed. Derek Bousfield and Miriam A. Locher 211-230. Walter de Gruyter.

Spencer-Oatey, Helen. 2002. Managing Rapport in Talk: Using Rapport Sensitive Incidents to Explore the Motivational Concerns Underlying the Management of Relations. Journal of Pragmatics 34 (5): 529-545. https://doi.org/10.1016/S0378-2166(01)00039-X.

Wang, Lu, and Guodong Zhao. 2011. Hamlet's Communication Strategies-A Review of Hamlet from Sociolinguistics Approach. Theory and Practice in Language Studies 1 (6): 694697.https://www.sparknotes.com/shakespeare/hamlet/doi:10.4304/tpls.1.6.694-697. 